\title{
Tinjauan Yuridis Akibat Hukum Perjanjian Harta Bersama yang Dibuat Oleh Suami Istri Setelah Perkawinan Berdasarkan Putusan Mahkamah Konstitusi Nomor 69/PUU-XIII/2015
}

\author{
Abdul Hariss ${ }^{1}$, Nurul Wulan Kasmara ${ }^{2}$ \\ Fakultas Hukum Universitas Batanghari Jambi
}

\begin{abstract}
Abstrak. Perkawinan merupakan suatu perjanjian yang diadakan oleh dua orang dalam hal ini perjanjian antara seorang pria dengan seorang wanita dengan tujuan material, yakni membentuk keluarga (rumah tangga) bahagia dan kekal yang berdasarkan Ketuhanan Yang Maha Esa, sebagai asas pertama dalam Pancasila. Dalam perkawinan yang dilakukan salah satunya akan melahirkan akibat perkawinan terhadap harta kekayaan. Semakin berkembangnya situasi dan kondisi di masyarakat banyak para calon pasangan yang akhirnya memutuskan untuk membuat Perjanjian Kawin mengingat hal ini dikarenakan baik pihak laki-laki maupun perempuan mampu menghasilkan harta kekayaan masingmasing dan masih banyak alasan lain kenapa harus membuat perjanjian kawin. Pada dasarnya tidak ada percampuran harta kekayaan dalam perkawinan antara suami dan istri. Konsep harta bersama pada awalnya berasal dari adat istiadat atau tradisi yang berkembang di Indonesia. Konsep ini kemudian didukung oleh Hukum Islam dan Hukum Positif yang berlaku dinegara kita. Maka di buatlah perjanjian harta bersama. Perjanjian Kawin adalah perjanjian yang dibuat oleh dua orang (calon suami istri) sebelum dilangsungkannya perkawinan. Perjanjian Kawin telah diatur dalam Pasal 29 Undang-Undang No. 1 Tahun 1974 namun dengan lahirnya Putusan Mahkamah Konstitusi No. 69/PUUXIII/2015 terjadi beberapa perubahan dalam Perjanjian Kawin yang saat ini masih menjadi Pro Kontra di dalam masyarakat. Permasalahan yang diteliti dalam penelitian ini adalah: bagaimana pengaturan perjanjian kawin di Indonesia dan bagaimana akibat hukum perjanjian kawin yang dibuat setelah perkawinan yang didasarkan pada Putusan Mahkamah Konstitusi No. 69/PUU-XIII/2015. Metode pendekatan yang digunakan adalah penelitian hukum normatif. Sumber bahan hukum yang digunakan adalah sumber bahan hukum primer dan sumber bahan hukum sekunder berupa buku-buku dan Perundang-Undangan. Teknik pengumpulan bahan hukum dilakukan dengan studi dokumenya itu membaca dan mempelajari buku-buku peraturan Perundang-Undangan. Adapun analisis bahan hukum di dalam penelitian ini, dilakukan dengan mengolah dan menganalisis secara kualitatif dan dituangkan secara deskriptif. Hasil penelitian pada simpulan pertama bahwa pengaturan perjanjian kawin di Indonesia terdapat dalam beberapa Undang-Undang antara lain KUHPerdata, UU Perkawinan No. 1 Tahun 1974, KHI dan Putusan Mahkamah Konstitusi No. 69/PUU-XIII/2016, dan pada simpulan hasil penelitian yang kedua terdapat perbedaan antara Perjanjian Kawin yang di atur dalam Pasal 29 Undang-Undang No. 1 Tahun 1974 dengan Perjanjian Kawin yang diatur dalam Putusan Mahkamah Konstitusi No. 69/PUU-XIII/2015.
\end{abstract}

Kata Kunci : Perjanjian Harta Bersama, Perjanjian Perkawinan, Akibat Hukum.

Abstract. A marriage is a commitment between two people, in this case a man and woman, with material purpose to build a happy and everlasting family (household) based on Belief in the one and only God which is the first principle of Pancasila(Five Principles). Asset/property issue may arise due to marriage. The development of society's mindset lead them to enter into a prenuptial agreement before they get married considering that both husband and wife are able to earn asset/property. Besides that, there are many other reasons to enter into a prenuptial agreement. Basically there is no mixture of wealth in marriage between husband and wife. The bconcept of shared assets originally came from customsnor traditions that developed in indonesia. This concept is then suported by islamic law and positive laws that apply in our country. Then a joint proprty agreement was made. Prenuptial Agreement is an agreement which is made by two people (betrothed couple) before they get married. Prenuptial Agreement had been stipulated in Article 29 Law No. 1 of 1974. However, since the Constitutional Court issued the Decision No. 69/PUU-XIII/2015, Prenuptial Agreement has several modifications which are presently being pros and cons in society. The matter which is being researched in this thesis is: what is the legal consequence of a prenuptial agreement which is made after marriage and based on the Decision of Constitutional Court No. 69/PUU-XIII/2015. The approach method which is used herein is normative legal research. The law material sources are primary law material and secondary law material in form of books and Legislation. Data analyses used in this research are processing and analyzing the data

\footnotetext{
${ }^{1}$ Abdul Hariss, Fakultas Hukum Universitas Batanghari Jambi

${ }^{2}$ Nurul Wulan Kasmara, Fakultas Hukum Universitas Batanghari Jambi
} 
qualitatively andthen descriptively drawn up. The result of this research found the differences between Prenuptial Agreement which is stipulated in Article 29 Law No. 1 of 1974 and the Prenuptial Agreement which is stipulated in the Decision of Constitutional Court No. 69/PUU-XIII/2015.

Keywords: Joint Property Agreement, Postnuptial Agreement, Legal Effect.

\section{PEDAHULUAN}

Negara Indonesia adalah negara hukum, termuat dalam Pasal 1 Ayat (3) UUD 1945 perubahan ke-4. Ketentuan pasal tersebut merupakan landasan konstitusional bahwa Indonesia adalah negara yang berdasarkan atas hukum, hukum ditempatkan sebagai satu-satunya aturan main dalam kehidupan bermasyarakat, berbangsa dan bernegara (supremacy of law). Ketentuan ini berasal dari Penjelasan Undang-Undang Dasar Negara Republik Indonesia Tahun 1945 yang "diangkat" ke dalam Undang-Undang Dasar Negara Republik Indonesia Tahun 1945. Unsur konsepsi negara hukum yang berasal dari tradisi Anglo Saxon (the rule of law) di dalam Undang-Undang Dasar Negara Republik Indonesia Tahun 1945 terlihat dari bunyi pasal 27 ayat (1) yang menegaskan bahwa "Segala warga negara bersamaan kedudukannya di dalam hukum dan pemerintahan dan wajib menjunjung hukum dan pemerintahan itu dengan tidak ada kecualinya."

Salah satu hukum yang berlaku di Indonesia adalah hukum Perdata. Hukum bisa dilihat sebagai perlengkapan masyarakat untuk menciptakan ketertiban dan keteraturan dalam kehidupan masyarakat. Oleh karena itu hukum bekerja dengan cara memberikan petunjuk tentang tingkah laku dan karena itu pula hukum berupa norma dalam bermasyarakat.

Takdir hidup berkelompok dalam suatu gugus yang disebut masyarakat, kenyataannya banyak membawa kegunaan. Berjuta-juta manfaat dapat digunakan oleh manusia lewat hidup bersama, baik dalam urusan pemenuhan kebutuhan hayati raga maupun jiwa. Bahkan cara hidup berdampingan serta berinteraksi dengan sesamanya, kian menjadi mudah memenuhi segala jenis kebutuhan yang di perlukan. Interaksi antara anggota kelompok, terbukti dapat mengujudkan jaringan eklusif untuk membentuk pola pemenuhan kebutuhan yang amat efisien ${ }^{3}$.

Manusia sebagai makhluk sosial memiliki naluri untuk berinteraksi dan hidup bersama dengan sesamanya. Naluri tersebut menimbulkan dorongan dalam diri setiap manusia untuk hidup bersama, yang diwujudkan dalam bentuk perkawinan. Perkawinan merupakan satu-satunya bentuk kehidupan bersama antara dua individu yaitu laki-laki dan perempuan yang diakui secara sah oleh Negara dan dilindungi oleh hukum yang berlaku, sebagaimana dikatakan oleh Paul Scholten bahwa "Perkawinan adalah hubungan pria dan wanita untuk hidup bersama yang mana hubungan itu bersifat kekal dan diakui negara." 4

Peraturan tentang perkawinan itu sendiri di Indonesia diatur dalam Undang-Undang Nomor 1 Tahun 1974 tentang Perkawinan, dimana dalam pasal 1 mendefinisikan Perkawinan ialah ikatan lahir batin antara seorang pria dengan seorang wanita sebagai suami istri yang bertujuan membentuk keluarga (rumah tangga) yang bahagia dan kekal yang berdasarkan Ketuhanan Yang Maha Esa.” Berdasarkan definisi perkawinan dalam UndangUndang Nomor 1 Tahun 1974, dapat disimpulkan bahwa perkawinan adalah ikatan antara laki-laki dan perempuan yang mana ikatan tersebut tidak hanya sekedar ikatan jasmani saja, melainkan juga termasuk ikatan rohani di dalamnya. Disini ikatan rohani menurut Undang-Undang Nomor 1 Tahun 1974 juga berperan penting terhadap pembentukan keluarga (rumah tangga) yang bahagia dan kekal.

Berbeda dengan Kitab Undang-Undang Hukum Perdata, menurut Kitab Undang-Undang Hukum Perdata perkawinan hanyalah sebatas ikatan keperdataan saja. Hal tersebut dapat dilihat pada Pasal 26 Kitab Undang-Undang Hukum Perdata yang menyatakan "Undang-undang memandang soal perkawinan hanya dalam hubungan-hubungan perdata". Berdasarkan hal tersebut, maka diketahui bahwa Kitab UndangUndang Hukum Perdata mengesampingkan urusan kerohanian dan hal tersebut dianggap tidak penting selama tidak diatur dalam hubungan hukum perdata. ${ }^{5}$

Perkawinan sebagai lembaga hukum, mempunyai akibat yang penting dalam kehidupan para pihak yang melangsungkan perkawinan. Akibat hukum yang timbul dibagi menjadi dua kelompok, yang pertama

\footnotetext{
${ }^{3}$ Moch. Isnaeni, Hukum Perkawinan Indonesia, PT Refika Aditama, Bandung, 2016, Hal. 14

${ }^{4}$ R. Soetojo Prawirohamidjojo dan Asis Safioedin, Hukum Orang dan Keluarga, Alumni, Bandung, 1985, Hal. 10

5 Khomariah, Hukum Perdata, UMM Press, Malang, 2004, Hal. 38
} 
akibat hukum terhadap individu atau diri pribadi suami istri itu sendiri, dan yang kedua adalah akibat kebendaan yaitu akiba-takibat hukum terhadap harta kekayaan suami istri tersebut, baik yang sudah ada maupun yang akan diperoleh selama perkawinan berlangsung. Pengaturan mengenai harta benda dalam perkawinan diatur di dalam Pasal 35, Pasal 36 dan Pasal 37 Undang-Undang Nomor 1 Tahun 1974.

Dengan kata lain, dapat disimpulkan bahwa perjanjian perkawinan adalah suatu perjanjian yang dibuat oleh calon suami atau istri secara tertulis yang menyatakan bahwa mereka telah saling setuju dan mufakat untuk membuat pemisahan atas harta benda mereka masing-masing dalam perkawinan, dimana dengan ditandatanganinya perjanjian perkawinan tersebut maka semua harta mereka, baik harta yang mereka bawa sebelum mereka menikah maupun harta yang mereka peroleh setelah mereka menikah akan tetap menjadi milik mereka masing-masing. Demikian juga halnya dengan utang dari masing-masing pihak, akan tetap menjadi tanggung jawab dari pihak yang memiliki utang tersebut. ${ }^{6}$

Perjanjian perkawinan bukanlah perjanjian yang dibuat dalam rangka perceraian. Meski banyak anggapan di masyarakat apabila ada pasangan yang hendak melangsungkan perkawinan kemudian memutuskan untuk membuat perjanjian perkawinan, maka mereka mempersiapkan untuk perceraiannya. Terlepas dari anggapan negatif masyarakat tentang perjanjian perkawinan, ada nilai-nilai positif dibalik maksud dibuatnya perjanjian perkawinan tersebut, yaitu untuk memberikan perlindungan bagi suami istri yang akan terikat dalam suatu perkawinan. Sebagai contoh adalah, perjanjian perkawinan yang dibuat oleh pasangan yang berasal dari dunia bisnis, dimana salah satu pihak memiliki bidang usaha yang beresiko tinggi yang ada kalanya dapat mengalami kemunduran karena sangat tergantung pada situasi perekonomian.

Apabila salah satu pihak ingin mengajukan kredit pada bank dengan jaminan harta yang dimilikinya, maka utang yang akan timbul setelahnya hanya akan mengikat pihak yang terkait saja, sedangkan pasangannya akan terbebas dari kewajiban dan resiko pembayaran utang. Kemudian apabila debitur dinyatakan bangkrut maka harta kekayaannya saja yang akan disita oleh kreditur, sementara harta pasangannya tidak. Dengan demikian keluarganya masih bisa menjalankan kehidupan sehari-hari terutama menjamin kesejahteraan kedua belah pihak dan anak-anak dengan menggunakan harta yang dimiliki pasangannya sehingga tidak ada pihak lain yang dirugikan dalam hal ini. Pemahaman yang sesungguhnya mengenai perjanjian kawin akan merubah pandangan masyarakat mengenai pasangan yang membuat perjanjian kawin sebelum melangsungkan perkawinan dan memberikan kepastian bagi tiap pasangan dalam menjalankan bahtera rumah tangga.

Perihal perjanjian perkawinan diatur di dalam Pasal 29 Undang-Undang Nomor 1 Tahun 1974. Adapun ketentuan dari pasal tersebut adalah sebagai berikut :

a) persetujuan bersama dapat mengadakan perjanjian tertulis yang disahkan oleh Pegawai Pencatat Perkawinan, setelah mana isinya berlaku juga terhadap pihak ketiga sepanjang pihak ketiga tersangkut.

b) Perjanjian tersebut tidak dapat disahkan bilamana melanggar batas hukum, agama dan kesusilaan.

c) Perjanjian tersebut berlangsung semenjak perkawinan dilangsungkan.

d) Selama perkawinan berlangsung perjanjian tersebut tidak dapat diubah, kecuali bilamana dari kedua belah pihak ada persetujuan untuk mengubah dan perubahan tidak merugikan pihak ketiga.

Pasal Undang-Undang Nomor 1 Tahun 1974 di atas adalah salah satu pasal yang bersifat pelaksanaan, yang merupakan dasar hukum kebolehan bagi calon suami istri untuk mengadakan perjanjian perkawinan, sebab masalah harta benda dalam perkawinan telah diatur oleh sistem hukum sebelumnya, yakni menurut pola hukum yang ada berdasarkan pemisahan harta, dimana semua harta kekayaan pribadi dari suami maupun istri berada dibawah penguasaan masing-masing. Sehingga pada intinya Pasal 29 Undang-Undang Nomor 1 Tahun 1974 hanya mengatur bahwa :

a. Perjanjian perkawinan dapat diadakan pada waktu atau sebelum perkawinan dilangsungkan;

b. Perjanjian perkawinan harus tertulis, yang disahkan oleh Pegawai Pencatat Perkawinan;

c. Perjanjian tidak boleh melanggar batas-batas hukum, agama, dan kesusilaan;

${ }^{6}$ Annisa Istrianty, Akibat Hukum Perjanjian Perkawinan Yang dibuat Setelah Perkawinan Berlangsung, Privat Law, Volume 3, Fakultas Hukum Universitas Sebelas Maret, Surakarta, 2015, Hal. 85 
d. Perjanjian perkawinan berlaku terhadap pihak ketiga setelah perjanjian tersebut disahkan oleh Pegawai Pencatat Perkawinan. Sedang berlaku terhadap kedua belah pihak, sejak perkawinan tersebut dilangsungkan;

e. Selama perkawinan berlangsung, perjanjian tersebut tidak dapat diubah, kecuali bila dari kedua belah pihak ada persetujuan untuk mengubah dan perubahan tidak merugikan pihak ketiga.

Jika suatu perkawinan dilangsungkan tanpa adanya perjanjian perkawinan, maka sesuai dengan ketentuan dalam Undang-Undang Nomor 1 Tahun 1974 harta yang diperoleh setelah perkawinan menjadi harta bersama, sehingga utang-utang yang timbul setelah dilangsungkannya perkawinan tersebut juga menjadi tanggung jawab bersama antara suami dan istri. Sedangkan apabila sebelum melangsungkan perkawinan pasangan calon suami istri sepakat untuk membuat perjanjian perkawinan terlebih dahulu, maka semua harta mereka baik harta yang mereka bawa sebelum menikah maupun harta yang mereka peroleh setelah menikah akan tetap menjadi milik mereka masing-masing.

Pada tanggal 27 Oktober 2016, Mahkamah Konstitusi mengeluarkan Putusan Nomor 69/PUUXIII/2015, dimana putusan tersebut telah merubah dan menambah norma pengaturan perjanjian perkawinan yang sebelumnya diatur dalam Pasal 29 Undang-Undang Nomor 1 Tahun 1974. Adapun perubahan dan penambahan norma tersebut adalah sebagai berikut :

a. Perjanjian perkawinan dapat dibuat sebelum, pada waktu dilangsungkan, atau selama dalam ikatan perkawinan dan dapat disahkan oleh Pegawai Pencatat Perkawinan atau oleh Notaris;

b. Perjanjian perkawinan mulai berlaku sejak perkawinan dilangsungkan, kecuali ditentukan lain dalam perjanjian perkawinan;

c. Perjanjian perkawinan dapat diubah atau dicabut dengan persetujuan para pihak sepanjang tidak merugikan pihak ketiga.

Adanya beberapa perubahan dan penambahan norma pada Putusan Mahkamah Konstitusi 69/2015 menimbulkan banyak problematika hukum, khususnya terkait dengan perjanjian perkawinan yang dibuat dalam masa ikatan perkawinan. Salah satu permasalahan yang dianggap menarik yaitu tentang akibat terhadap harta bersama yang timbul setelah perkawinan berlangsung apabila pasangan suami istri memutuskan untuk membuat perjanjian perkawinan dalam masa ikatan perkawinan tersebut. Sebagaimana diatur dalam Undang-Undang Nomor 1 Tahun 1974. Sehingga dengan dikeluarkannya Putusan Mahkamah Konstitusi 69/2015 ini yang membuka peluang bagi suami istri untuk membuat perjanjian perkawinan selama dalam masa ikatan perkawinan, muncul permasalahan salah satunya terkait dengan penyelesaian atas harta bersama.

\section{METODE PENELITIAN}

Penelitian hukum yang digunakan dalam penyusunan proposal skripsi ini merupakan tipe penelitian hukum normatif. Penelitian hukum normantif dilakukan dengan cara meneliti peraturan PerundangUndangan dan kepustakaan hukum. Sedangkan pendekatan masalah yang digunakan adalah peraturan Perundang-Undangan,konseptual dan perbandingan hukum. Sumber bahan hukum yang penulis gunakan adalah sumber bahan hukum yang berkaitan dengan rumusan masalah.

\section{HASIL DAN PEMBAHASAN}

\section{Tinjauan Yuridis Akibat Hukum Perjanjian Harta Bersama Yang Dibuat Oleh Suami Istri Setelah Perkawinan Berdasarkan Putusan Mahkamah Konstitusi Nomor 69/Puu-Xiii/2015}

Di Indonesia, terdapat 3 (tiga) produk peraturan perundang-undangan yang mengatur masalah perjanjian perkawinan, yaitu:

1. Kitab Undang-Undang Hukum Perdata (KUHPerdata) atau Burgerlijk Wetboek(BW)

Menurut Pasal 1313 Kitab Undang-Undang Hukum Perdata, Pasal 139 Kitab Undang-Undang Hukum Perdata menyatakan Dalam aturan pasal 147BW dinyatakan bahwa perjanjian perkawinan harus dibuat sebelum perkawinan dilangsungkan dan perjanjian perkawinan harus dibuat dihadapan notaris. Jika perjanjian perkawinan tidak dibuat dihadapan notaris maka perjanjian itu batal dari hukum.

Perjanjian atau perikatan, perikatan mempunyai arti yang lebih luas dan umum dari perjanjian,sebab dalam Kitab Undang-Undang Hukum Perdata lebih dijelaskan secara jelas. Adapun yang 
dimaksud dengan perikatan dalam Kitab Undang-Undang Hukum Perdata Pasal 1233 "Perikatan, lahir karna suatu persetujuan atau karna undang-undang".

2. Undang-Undang Nomor 1 tahun 1974 mengenai Perkawinan

Dalam Undang-undangPerkawinanNo. 1 tahun 1974 pasal 29

3. Kompilasi Hukum Islam

Dalam Kompilasi hukum Islam pasal 47.

Sejak berlakunya Undang-Undang Nomor 1 tahun 1974, sehingga di negara Indonesia telah terjadi unifikasidalam bidang Hukum Perkawinan, kecuali sepanjang yang belumatau tidak diatur dalam undangundang tersebut, maka peraturan lama dapat dipergunakan. ${ }^{7}$

Pengajuan uji materiil terhadap pasal tersebut di Mahkamah Konstitusi menghasilkan keputusan yang cukup signifikan. Hal demikian sesuai dengan pendapat Herma yanti bahwa Mahkamah Konstitusi adalah fungsi peradilan untuk menegakkan hukum dan keadilan, dalam rangka menegakkan supremasi konstitusi. ${ }^{8}$ Oleh karena itu, pada tanggal 27 Oktober 2016, dengan nomor 69/PUU-XIII/2015, dalam amarnya majelis memutuskan bahwa, "Pada waktu, sebelum dilangsungkan atau selama dalam ikatan perkawinan kedua belah pihak atas persetujuan bersama dapat mengajukan perjanjian tertulis yang disahkan oleh pegawai pencatat perkawinan atau notaris, setelah mana isinya berlaku juga terhadap pihak ketiga sepanjang pihak ketiga tersangkut". Dengan demikian, sebelum Oktober 2016 hanya boleh dibuat sebelum perkawinan atau dikenal dengan Prenuptial Agreement, maka setelahnya bisa juga selama perkawinan atau disebut Perjanjian Pasca Pernikahan ("Postnuptial Agreement"). Hukum Putusan Mahkamah Konstitusi Nomor 69/PUUXIII/2015:

a. Pada waktu, sebelum dilangsungkan, atau selama dalam ikatan perkawinan, kedua belah pihak atas persetujuan bersama dapat mengajukan perjanjian tertulis yang disahkan oleh Pegawai pencatat perkawinan atau notaris, setelah mana isinya berlaku juga terhadap pihak ketiga sepanjang pihak ketiga tersangkut.

b. Perjanjian tersebut tidak dapat disahkan bilamana melanggar batas-batas hukum, agama dan kesusilaan.

c. Perjanjian tersebut mulai berlaku sejak perkawinan dilangsungkan, kecuali ditentukan lain dalam Perjanjian Perkawinan.

d. Selama perkawinan berlangsung, perjanjian perkawinan dapat mengenai harta perkawinan atau perjanjian lainnya, tidak dapat diubah atau dicabut, kecuali bila dari kedua belah pihak ada persetujuan untuk mengubah atau mencabut, dan perubahan atau pencabutan itu tidak merugikan pihak ketiga.

Pasca dikeluarkannya putusan Mahkamah Konstitusi No.69/PUU-XIII/2015 terjadinya perubahan yang berkaitan dengan pembuatan perjanjian perkawinan, adanya putusan tersebut yang mana atas permohonan seorang warga negara Indonesia yang melakukan perkawinan campuran dengan warga negara Asing, yang melangsungkan perkawinannya dengan tanpa membuat perjanjian perkawinan terlebih dahulu. Dengan seiring berjalannya waktu pasangan tersebut bermaksud untuk membeli rusun (rumah susun/apartement), akan tetapi dalam ranahnya ada peraturan yang berlaku dalam konteks hukum tanah nasional yaitu ketentuan pada Undang-Undang Pokok Agraria dianutnya asas nasionalitas, yang artinya bahwa hanya Warga Negara Indonesia saja yang berhak memiliki hak atas tanah di negara Indonesia. Oleh sebabnya maka pemohon yang berkewarga negaraan Indonesia mengajuan permohonan constitution review (pengujian konstitusional) ke Mahkamah Konstitusi karena merasa dirugikan oleh adanya Pasal 21 ayat (1) dan ayat (3), Pasal 36 ayat (1) UUPA, Pasal 29 ayat (1), ayat (3), ayat (4), dan Pasal 35 ayat (1) UndangUndang Perkawinan.

Sebagai WargaNegara Indonesia (WNI) yang apabila menikah dengan Warga Negara Asing (WNA), maka perkawinan tersebut nerupakan perkawinan campuran yang mana diatur dalam Pasal 57 UndangUndang No.1 Tahun 1974 tentang Perkawinan yang menyatakan :"yang dimaksud dengan perkawinan campuran dalam Undang-undang ini ialah perkawinan antara dua orang yang di Indonesia tuntuk pada hukum yang berlainan, karena perbedaan kewarga negaraan dan salah satu pihak berkewarganegaraan

\footnotetext{
${ }^{7}$ K. Wantjik Saleh,Hukum Perkawinan Indonesia, Ghalia Indonesia, Jakarta, 1982, Hal. 6

${ }^{8}$ Herma Yanti, Gagasan constitutional Complaint Sebagai kewenangan Baru Mahkamah Konstitusi dalam Perlindungan Hak Konstitusional, Jurnal Wajah Hukum, Volume 2 Nomor 2 (Oktober 2018), Hal. 186
} 
Indonesia".Warga Negara Indonesia yang menikah dengan Warga Negara Asing, setelah perkawinannya tidak diperbolehkan untuk memiliki hak atas tanah yang berupa Hak Milik, Hak Guna Usaha ataupun Hak Guna Bangunan. Karena dengan Pasal 35 UU Perkawinan yang menjelaskan bahwa harta benda yang diperoleh selama perkawinan menjadi harta bersama. Oleh karena itu, ada pencampuran harta yang diperoleh setelah perkawinan, dan Warga Negara Asing akan turut menjadi pemilik atas harta bersama tersebut. Kemudian meliat lagi pada ketentuan undang-undang No.5 Tahun 1960 tentangPeraturan Dasar Pokok-Pokok Agraria, bahwa Warga Negara Asing tidak diperbolehkan meniliki Hak Milik, Hak Guna Usaha atau Hak Guna Bangunan. ${ }^{9}$

Permohonan tersebut Mahkamah Konstitusi memberikan pendapat dalam pertimbangan hukumnya menyebutkan bahwa, ketentuan yang berlaku pada saat ini hanya mengatur perjanjian perkawinan yang dibuat sebelum atau sesudah dilangsungkannya perkawinan, tetapi dalam kenyataannya bahwa ada kejadian yang mana antara suami isteri yang dengan alasan tertentu baru merasakan adanya kebutuhan untuk membuat perjanjian kawin selama mereka dalam ikatan perkawinan. Dengan adanya mengenai Pasal 29 Undang-Undang Nomor 1 Tahun 1974 bahwa perjanjian perkawinan seperti demikian yang dimaksud harus diadakan sebelum perkawinan dilangsungkan dan harus dicantuMahkamah Konstitusian dalam suatu akta Notaris. Perjanjian ini tentunya berlaku pada saat suami istri melangsungkan perkawinan. Kemudian isi dari perjanjian perkawinan tersebut hanya tergantung pada para pihak antara calon suami dan istri, dan tentunya tidak bertentangan dengan Undang-Undang, agama, dan kesusilaan serta dalam pembuatan perjanjian perkawinan para pihak suami isteri diberikan kebebasan (kebebasan berkontrak).

Menurut pendapat saya, walaupun di dalam putusan Mahkamah Konstitusi No. 69/PUU-XII/2015 dinyatakan bahwa para pihak dapat menetapkan kapan saat mulai berlakunya Postnuptial Agreement,namun kami berpendapat bahwa Postnuptial Agreement hanyalah mengatur terhadap harta-harta yang akan diperoleh kemudian sejak akta Postnuptial Agreement tersebut dibuat. Artinya tidak termasuk pada hartaharta yang diperoleh sebelum Postnuptial Agreement tersebut dibuat. Demikian pula, mengenai syarat berlakunya Postnuptial Agreement ini harus secara tegas menyebutkan bahwa postnup ini tidak boleh merugikan pihak ketiga.

Jadi, walaupun dalam Putusan Mahkamah Konstitusi No. 69/PUU-XII/2015 Notaris berhak untuk membuat dan mengesahkan suatu Perjanjian Pasca Pernikahan atau Postnuptial Agreement, namun agar Postnuptial Agreement tersebut sah mengikat bagi pihak ketiga baru bisa terjadi jika sudah di daftarkan pada Instansi Pelaksana atau Unit Pelaksana Teknis (UPT) Instansi Pelaksana, yaitu Kantor Catatan Sipil untuk pasangan kawin non muslim dan Kantor Urusan Agama untuk yang muslim.

Menurut Analisis saya dari data yang telah di uraikan sebelumnya, Akibat dari putusan Mahkamah Konstitusi ini yang mana telah menciptakan atau meniadakan satu keadaan hukum yang baru atau membentuk hukum yang baru kemudian putusan tersebut mempunyai kekuatan hukum yang mengikat sejak diumum-kannya.Terkait dengan pencatatan perjanjian perkawinan yang dibuat sepanjang perkawinan tentunya harus juga diperhatikan dimana ketika melakukan praktek ternyata masih adanya hambatanhambatan teknis di dalam melakukan pencatatan perjanjian perkawinan, karena ternyata pejabat kantor catatan sipil hanya berpegang pada petunjuk teknis terkait dengan pencatatan perkawinan, yang mengabaikan ketentuan peraturan perundang-undangan yang telah ditentukan terkait dengan pencatatan perjanjian perkawinan.

Maka akibat perjanjian perkawinan yang berkenaan dengan harta kekayaan, terdapat perbedaan prinsipil antara ketentuan yang diatur dalam Kitab Undang-Undang Hukum Perdata (KUHPdt) dan UndangUndang Perkawinan. Dalam Kitab Undang-Undang Hukum Perdata ditentukan apabila tidak diadakan perjanjian, sejak perkawinan berlangsung "terjadi penyatuan harta kekayaan" suami dan istri. Sebaliknya, dalam Undang-Undang Perkawinan ditentukan apabila tidak diadakan perjanjian perkawinan, sejak perkawinan dilangsungkan "harta kekayaan suami dan harta kekayaan istri tetap dikuasai oleh masingmasing pihak" (Pasal 35 ayat (2) Undang-Undang Perkawinan).

Akibat hukum adanya perjanjian perkawinan antara suami dan istri adalah sebagai berikut:

9 http://www.hukumonline.com/klinik/detail/lt4c529ced60c02/permasalahan-perkawinan-campuran-dan-harta-bersama di akses tanggal 5 Februari 2019, Pukul 14.45 WIB 
a) Perjanjian mengkiat pihak suami dan pihak istri;

b) Perjanjian mengikat pihak ketiga yang berkepentingan;

c) Perjanjian hanya dapat diubah dengan persetujuan kedua pihak suami dan istri, dan tidak merugikan kepentingan pihak ketiga, serta disahkan oleh pegawai pencatat perkawinan.

Akibat hukum yang ditimbulkan oleh persatuan harta kekayaan perkawinan adalah perbuatan hukum atas persatuan hanya sah apabila dilakukan bersama-sama oleh suami dan isteri, karena pemilik benda adalah kedua orang suami isteri itu secara bersama-sama. Misalnya suami dalam suatu perkawinan tanpa perjanjian kawin membawa sebidang tanah yang sebelum perkawinan diselenggarakan tanah tersebut telah disertifikatkan atas namanya.

1. Menurut Kitab Undang-undang Hukum Perdata

Jika sebelum perkawinan dilangsungkan calon suami isteri tidak membuat perjanjian kawin (tentang pembatasan atau peniadaan persatuan harta kekayaan perkawinan), maka dalam perkawinan tersebut terjadipersatuan bulat harta kekayaan perkawinan (Pasal 119 KUH Perdata). Persatuan bulat ini terjadi demi hukum. Hal ini berarti bahwa dengan dilangsungkannya perkawinan, maka secara otomatis demi hukum harta kekayaan suami isteri menjadi milik bersama suami isteri yang bersangkutan, tanpa diperlukan adanya penyerahan atau perbuatan hukum lainnya. Dengan kata lain, begitu begitu seorang pria kawin dengan seorang wanita tanpa didahului pembuatan perjanjian kawin, maka demi hukum terjadilah persatuan bulat harta kekayaan perkawinan di antara mereka. Persatuan itu sepanjang perkawinan tidak boleh ditiadakan atau diubah dengan sesuatu persetujuan antar suami-istri.

Menurut Pasal 120-121 Kitab Undang-undang Hukum Perdata, persatuan bulat, meliputi:

a. Benda bergerak dan tidak bergerak baik yang dimiliki sekarang maupun kemudian hari.

b. Hasil, penghasilan dan keuntungan yang diperoleh selama perkawinan.

c. Utang-utang suami/istri sebelum dan sesudah perkawinan.

d. Kerugian-kerugian yang dialami selama perkawinan.

2. Menurut Undang Undang Perkawinan No. 1 Tahun 1974

Pasal 35,36, dan 37 Undang-Undang Perkawinan mengatur tentang harta kekayaan dalam perkawinan. Menurut ketentuan pasal tersebut, harta kekayaan dalam perkawinan dibedakan menjadi 2 macam. Pertama, harta bersama yang diperoleh suami dan istri selama dalam ikatan perkawinan. Kedua, harta bawaan yang dibawa oleh masing-masing suami dan istri ketika terjadi perkawinan.

Tujuan dibuatnya perjanjian perkawinan :

a. Membatasi atau meniadakan sama sekali kebersamaan harta kekayaan menurut undang-undang.

b. Pemberian hadiah kepada istri atau sebaliknya atau pemberian timbal balik antara suami istri

c. Membatasi kekuasaan suami terhadap barang bersama yang ditentukan undang-undang.

d. Pemberian pihak ketiga kepada suami istri.

Dengan adanya Putusan Mahkamah Konstitusi Nomor 69/PUU-XIII/2015, yang mana putusan tersebut besifat final, berkekuatan hukum tetap dan mengikat sejak di ucapkan atau diputuskannya. Artinya bahwa putusan tersebut mengikat para pihak yang berperkara dan juga mengikat seluruh warga negara Indonesia, lembaga ataupun badan hukum lainnya. Selain itu juga tentunya mengikat para Notaris yang manawewenangnya sebagai pejabat dalam pembuatan akta perjanjian serta juga dinas kependudukan dan pencatatan sipil maupun kantor urusan agama selaku pejabat yang berwenang mencatatkan akta perjanjian perkawinan.Pelaksanaan pembuat perjanjian perkawinan di dalam UU No.1 Tahun 1974 tentang perkawinan pasca putusan Putusan Mahkamah Konstitusi Nomor 69/PUU-XIII/2015, tentunya di dalam membuat perjanjian diantara kedua belah pihak yang ingin membuat perjanjian tersebut harus memenuuhi syaratsyarat yang telah di tentukan dalam Pasal 1232 KUH Perdata. Pelaksanaan pembuatan perjanjian perkawinan bisa dilakukan pada waktu sebelum ataupun selama dalam masa ikatan perkawinan. Karena hal ini telah diatur dalam Pasal 29 Undang-Undang Perkawinan jo. Putusan Mahkamah Konstitusi Nomor 69/PUU-2015. Bawa pembuatan perjanjian perkawinan dapat dibuat sebelum maupun sesudah perkawinan berlangsung. Pasca putusan Putusan Mahkamah Konstitusi Nomor 69/PUU-XIII/2015 pembuatan perjanjian perkawinan yang dibuat Notaris hanya mengganti pada bagian premisse saja. Kemudian dari pada 
itu pembuatan perjanjian perkawinan yang dibuat oleh Notaris tentunya akta tersebut dibuat atas dasar para pihak yang menghendaki pembuatan perjanjian perkawinan itu sendiri dan tentunya tidak bertentangan dengan peraturan perundang-undangan yang telah berlaku.Hambatan dan solusi dalam pelaksanaan pembuatan perjanjian perkawinan di dalam UU No.1 Tahun 1974 tentang Perkawinan pasca Putusan Mahkamah Konstitusi Nomor 69/PUU-XIII/2015 terhadap Notaris, hambatan yang ada dari pelaksanaan pembuatan perjanjian perkawinan belum dibuatnya ketentuan yang baru untuk mengatur tata cara pencatatan perjanjian perkawinan yang dibuat pada saat perkawinan telah berlangsung. Mengatasi hambatan tersebut tentunya Menteri dalam Negeri harusnya menyegerakan untuk mengeluarkan peraturan terkait dengan pencatatan perjanjian perkawinan, juga mengenai pencatatan perjanjian perkawinan yang dibuat sepanjang perkawinan, yang segera diikuti dengan dikeluarkannya perihal pencatatan perjanjian perkawinan tersebut. Oleh sebab itu jika sepanjang belum adanya ketentuanmengenai pencatatan perjanjian perkawinan yang dibuat pada saat perkawinan berlangsung maka tentunya pencatatan belum dapat dilakukan, dan jika perjanjian perkawinan belum dicatatkan maka perjanjian perkawinan tersebut tidak mengikat pihak ketiga dan hanya berlaku diantara para pihak. Kemudian hambatan jika dalam pembuatan perjanjian perkawinan yaitu misalnya apabila para pihak tidak berterus terang terhadap pengajuan akta yang dikehendakinya terkait dengan data-data ataupun tentang apa saja isi dari perjanjian perkawinan tersebut. Untuk itu solusinya maka seorang Notaris jika ingin membuatkan akta perjanjian perkawinan harus lebih teliti lagi atas data data yang diberikan oleh para pihak yang menghadap untuk melakukan pembuatan perjanjian perkawinan.

\section{SIMPULAN}

1. Berdasarkan paparan diatas, maka ketentuan untuk membuat perjanjian harta bersama yang dibuat oleh suami istri setelah perkawinan menggunakan Pasal 29 Undang-Undang Perkawinan jo Putusan Mahkamah Konstitusi Nomor 69/PUU-XIII/2015. Warga Negara Indonesia yang menikah dengan Warga Negara Asing, setelah perkawinannya diperbolehkan untuk memiliki hak atas tanah yang berupa Hak Milik, Hak Guna Usaha ataupun Hak Guna Bangunan, apabila telah melaksanakan perjanjian perkawinan yang catat di Notaris yang manawewenangnya sebagai pejabat dalam pembuatan akta perjanjian serta juga dinas kependudukan dan pencatatan sipil maupun kantor urusan agama selaku pejabat yang berwenang mencatatkan akta perjanjian perkawinan.

2. Akibat hukum dari perjanjian perkawinan yaitu mengikat pihak-pihak yang membuatperjanjian perkawinan sebagai Undang-Undang bagi kedua belah pihak dan pihak ketiga tersangkut. Dibuatnya perjanjian kawin yang dibuat setelah perkawinan pasca putusan Mahkamah Kontitusi No. 69/PUUXIII/2015 membawa akibat terhadap perubahan status hukum harta benda yang terdapat atau diperoleh di dalam perkawinantersebut. Dengan demikian seharusnya pembuatan perjanjian perkawinan tersebut tidak boleh merugikan pihak ketiga. Bagi pihak ketiga yang menjadi kreditur, adalah penting untuk mengetahui bagai mana kedudukan harta kekayaan suami-istri. Hal ini berkait dengan kepastian terlunasinya piutang. Kedudukan hukum perjanjian perkawinan yang dibuat setelah perkawinan terhadap pihak ketiga kekuatan mengikatnya adalah terhitung sejak didaftarkan. Dalam hubungannya dengan pihak ketiga, perjanjian kawin tersebut mengikat kedepan dan tidak berlaku surut.

\section{DAFTAR PUSTAKA}

\section{Buku-Buku}

Annisa Istrianty, Akibat Hukum Perjanjian Perkawinan Yang dibuat Setelah Perkawinan Berlangsung, Privat Law, Volume 3, Fakultas Hukum Universitas Sebelas Maret, Surakarta, 2015

H.A. Damanhuri HR, Segi-Segi Hukum Perjanjian Perkawinan Harta Bersama, Mandar Maju, Jakarta, 2007

K. Wantjik Saleh,Hukum Perkawinan Indonesia,Ghalia Indonesia, Jakarta, 1982.

Khomariah, Hukum Perdata, UMM Press, Malang, 2004

Moch. Isnaeni, Hukum Perkawinan Indonesia, PT Refika Aditama, Bandung, 2016

Rusdi Malik,Undang-undang Perkawinan, Penerbit Universitas Trisakti, 2003

R. Soetojo Prawirohamidjojo dan Asis Safioedin, Hukum Orang dan Keluarga, Alumni, Bandung, 1985

Jurnal 
Herma Yanti, Gagasan constitutional Complaint Sebagai kewenangan Baru Mahkamah Konstitusi dalam Perlindungan Hak Konstitusional, Jurnal Wajah Hukum, Volume 2 Nomor 2 (Oktober 2018)

Peraturan Perundang-Undangan

Kitab Undang-Undang Hukum Perdata (KUHPerdata)

Undang-Undang No. 1 Tahun 1974 Tentang Perkawinan

Kompilasi Hukum Islam (KHI)

Putusan Mahkamah Konstitusi Nomor 69/PUU-XIII/2015

Internet

http://www.hukumonline.com/klinik/detail/lt4c529ced60co2/permasalahan-perkawinan-campuran-danharta-benda-bersama 